The Communities of the Nematodes, Bacteria, and Fungi and the Soil's Organic Matter in an Agroforestry Ecosystem in Croatia

Zajednice nematoda, bakterija i gljiva i sadržaj humusa $u$ agrošumarskome ekosustavu u Hrvatskoj

Puškarić, J., Jović, J., Ivezić, V., Popović, B., Paponja, I., Brmež, M.

Poljoprivreda/Agriculture

ISSN: $1848-8080$ (Online)

ISSN: 1330-7142 (Print)

https://doi.org/10.18047/poljo.27.1.9

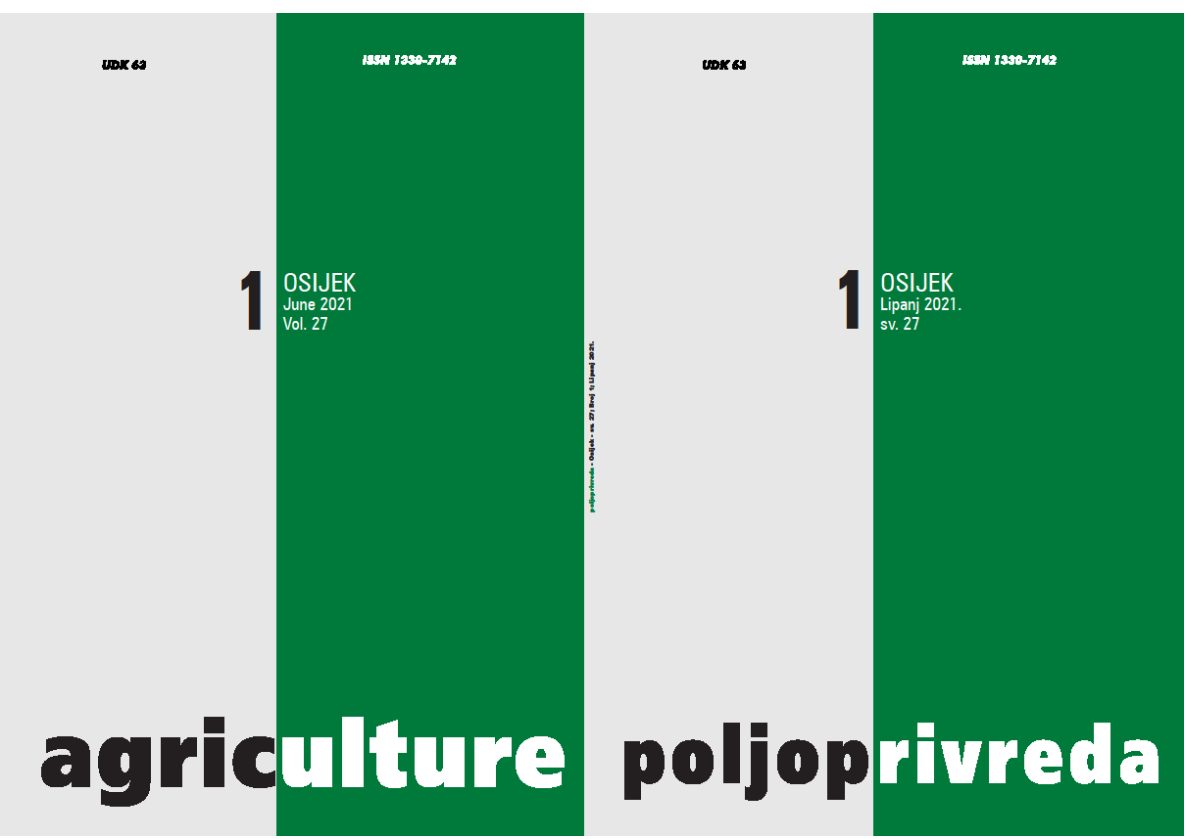

Fakultet agrobiotehničkih znanosti Osijek, Poljoprivredni institut Osijek

Faculty of Agrobiotechnical Sciences Osijek, Agricultural Institute Osijek 


\title{
THE COMMUNITIES OF THE NEMATODES, BACTERIA, AND FUNGI AND THE SOIL'S ORGANIC MATTER IN AN AGROFORESTRY ECOSYSTEM IN CROATIA
}

Puškarić, J., Jović, J., Ivezić, V., Popović, B., Paponja, I., Brmež, M.

Original scientific paper

Izvorni znanstveni članak

\begin{abstract}
SUMMARY
An above-ground plant diversity affects a below-ground biodiversity. A soil fauna diversity is important for the ecosystems' sustainability. It reflects both the abiotic conditions and the soil's biotic activity. This study's objective was to assess the effect of an agroforestry system on the nematode abundance and trophic group distribution and on the bacterial and fungal abundance in the soil, as well as to analyze the links between a nematode abundance, trophic group patterns, soil's microbiological status and the organic matter. A field experiment was conducted during two years in three treatments and three sampling periods. The treatments were as follows: an agricultural crop (C), a permanent walnut plantation (W), and a permanent walnut plantation with an agricultural crop $(C+W)$. The nematodes were extracted, counted, processed and mounted on slides and ultimately determined and assigned to the trophic groups. The bacteria and fungi were extracted from the soil, grown on the plates, and counted. Our findings suggest that the studied agroforestry system $(C+W)$ has exerted a positive effect on the soil nematodes, bacteria, and fungi, manifested as the statistically highest abundance of bacteria and fungi, but also as the highest abundance of nematodes and of a diversity of the nematode genera. The highest content of the organic matter was detected in the treatment $C+W$ in the first sampling and in the treatments $C+W$ and $W$ in the second sampling. We have concluded that the combination of an agricultural crop and a permanent plantation has a great potential for better ecosystem stability and sustainability regardless of some deviations in our results. We believe that a further research is necessary because the different agroforestry ecosystems may have different impacts on the soil fauna.
\end{abstract}

Keywords: nematode trophic groups, soil fauna, microorganisms, walnut plantation, agricultural crop

\section{INTRODUCTION}

Soil organisms represent a crucial part of Earth's biosphere, as the human race depends on a soil system functioning. Numerous soil processes generated by different soil organism groups are to be credited for the healthy soils (Ferris and Tuomisto, 2015). The soil organisms have the roles of decomposers, nutrient transformers, ecosystem engineers and biocontrollers (Kibblewhite et al., 2008), and some of them possess the traits that render them useful as ecological indicators.

A community structure study of soil organisms such as the nematodes may provide us with an insight into the soil processes and the soil status (Ritz and Tradgill, 1999). The nematodes are used as bioindicators because of their ubiquity, diversity, and abundance and because of their rapid reaction to the environmental changes (Neher at al., 2005; Brmež et al., 2018). The nematode communities are studied to estimate the soil disturbances and to monitor the soil's ecological condition (Bongers, 1990; de Goede, 1993). In addition, the

Josipa Puškarić, M. Eng. Agr., Jurica Jović, Ph. D. (jjovic@fazos.hr), Asst Prof. Vladimir Ivezić, Assoc. Prof. Brigita Popović, Ivan Paponja, M. Eng. Agr, Ph. D. student, Prof. Dr. Mirjana Brmež - Josip Juraj Strossmayer University of Osijek, Faculty of Agrobiotechnical Sciences Osijek, Vladimira Preloga 1, Osijek, Croatia 
nematode sampling and extraction methods are easily applied, and the nematodes are assigned to the trophic groups based on a morphological structure of their mouth cavity (Neher et al., 2005). The nematode trophic groups are heterogeneous. One group interacts in the ecosystems as the plant herbivores directly, while the other interacts indirectly as a microflora consumer, thus regulating the organic matter decomposition and the distribution of nutrients (Urzelai et al., 2000).

The nematode species' richness and the trophic structures of nematode communities are being modified in response to the soil perturbations caused by the fertilization with mineral nitrogen, cultivation, liming, heavy metal accumulation, pollution, as well as to any other natural or anthropogenic disturbances in an ecosystem (Neher et al., 1998; Urzelai et al., 2000).

The free-living nematodes i.e., the ones that feed on the bacteria and fungi, reflect the bacterial and fungal conditions in the soil. These nematodes affect a size of the soilborne microbial and fungal communities, as well as their structure and activity (Ingham et al., 1985; Venette and Ferris, 1998). The microbes contribute to the nutrient cycling and decomposition of the organic matter. While grazing on those microbes, the nematodes play an important role in the soil's $\mathrm{N}$ mineralization (Ferris et al., 1998; Bardgett and Chan, 1999). A nematode excretion may contribute up to $27 \%$ of the soluble nitrogen in the natural ecosystems and agroecosystems (Ekschmitt et al., 1999).

The modifications in a microbial community may effectuate the reduced decomposition rates and a capacity to reduce pollution in the soil (Bardgett and van der Putten, 2014). The anthropogenically triggered modifications in soil may impact a soil quality and resilience, implying the soilborne processes and function as well (Wagg et al., 2014).

One of the solutions for improving the soil health and its biodiversity may be found in agroforestry, a combination of woody species and crops. This combination reduces the negative impacts of climate on an agricultural production and creates a new microclimate within plantations (Verchot et al., 2007). Beside crop diversity in a growing season, the main advantage of intercropping is a positive effect on soil fertility, disease, pest, and weed protection, a better utilization of nutrients and water in the soil, and an increased biodiversity (Dupraz et al., 2005). Therefore, the human-induced modifications are being reduced.

This study's objective was to determine the effect of an agroforestry system on the nematode abundance and trophic group patterns and on the bacterial and fungal abundance, as well as to analyze the links between a bacterial and fungal abundance and the organic matter, with a nematode abundance and feeding group distribution.

\section{MATERIAL AND METHODS}

The field experiment was set up in August 2017 at the Đakovo site, Osijek-Baranja County $\left(45^{\circ} 18^{\prime} 24.09^{\prime \prime} \mathrm{N}\right.$, $18^{\circ} 25^{\prime} 59.95^{\prime \prime} \mathrm{E}$, and $\left.45^{\circ} 18^{\prime} 21.69^{\prime \prime} \mathrm{N}, 18^{\circ} 26^{\prime} 20.48^{\prime \prime} \mathrm{E}\right)$, in three different agrosystems representing three different treatments. The first treatment is an agricultural crop (C), the second treatment is a permanent walnut plantation with an agricultural crop between the walnut rows $(C+W)$, while the third treatment is a permanent walnut plantation with a meadow between the walnut rows (W). The experimental plots were sized from 1.05 to $1.35 \mathrm{ha}$. The observed permanent plantations (W and C + W) pertained to the 10-year-old grafted walnuts, with an 8-meter spacing between the rows and a 7-meter spacing within a row. In the $C+W$ treatment, an agricultural crop was sown while providing a 6 -meter width.

During the two research years, various crops were sown: wheat (October 2017 - July 2018), rapeseed as a green manure (August 2018 - April 2019), and buckwheat (May 2019 - September 2019). The green manure goal was to increase the organic matter content while encouraging a microbiological activity to decompose the juglone. Considering that walnut acidifies the soil, the agricultural crops tolerating an acidic soil were used in this field experiment.

The study material consisted of the samples for nematological, microbiological, and agrochemical analyses, and agroclimatological data were collected on the experimental surfaces. The agronomic measures implied the implementation of agrotechnical steps and the application of plant protection and fertilization products according to the organic production rules in each treatment. All agrotechnical and mechanical measures, as well as the organic inputs, were applied on the same day in each treatment.

The nematological analysis samples were collected by a nematological probe at a depth of 0 to $30 \mathrm{~cm}$. The sampling was systematic, and the subsamples were taken in the middle of the crop row or of the meadow, between every 5 th walnut in a tree row. The samples were collected on three occasions, 9 May 2018, 20 September 2018, and on 3 September 2019, respectively, in three treatments and four repetitions, with a total of 36 samples collected. The nematodes were extracted from the soil $(100 \mathrm{~g})$ by the Baerman funnel method (Van Bezooijen, 2006) and fixed in the 4-percent formalin till the semipermanent slides were prepared (Van Bezooijen, 2006). The nematodes were counted using a stereo zoom loupe (Olympus BX 16) and determined to match a generic level using the Olympus BX 50 microscope. A minimum of 100 nematodes was determined in each sample $(3,600$ nematodes). The nematode measurements were performed using a Promicra camera and QuickPHOTO MICRO 3.1. The determination of nematodes was performed according to Bongers (1994), Mai and Lyon (1975), and Andrassy (2005; 2007; 2009).

The nematodes were assigned to five most common trophic groups concerning the free-living ones: bacterivores $(\mathrm{Ba})$, fungivores $(\mathrm{Fu})$, phytoparasites $(\mathrm{Pp})$, omnivores $(0 \mathrm{~m})$ and predators (Pr) (Yeats et al., 1993; Wasilewska, 1997), based on their feeding type (Bongers and Bongers, 1998).

The samples used for the nematological analyses were also utilized for the microbiological ones to count a total number of bacteria and fungi in the soil. Subsequent to the soil sample homogenization, $1 \mathrm{~g}$ of 
each soil sample was separated and added into a flask with a saline solution, followed by a sample shaking. Different dilutions were prepared, i.e., the $10^{1}-10^{6}$ ones. To grow the plates, $1 \mathrm{ml}$ of each dilution was submitted under an appropriate medium using the potato dextrose agar (PDA, Liofilchem) for the fungi and the tryptic glucose yeast agar (TGA, Biolife) for the bacteria. In the PDA, a chloramphenicol supplement was added to inhibit a bacterial growth, and cycloheximide solution was added in the TGA to inhibit a fungal growth. The plates were incubated for $72 \mathrm{~h}$ at $28^{\circ} \mathrm{C}$ for the fungi and for $48 \mathrm{~h}$ at $30^{\circ} \mathrm{C}$ for the bacteria. A total number of bacteria and fungi was determined by the Koch method, by counting the colonies on an agar medium in the Petri dishes. Only the Petri dishes in which the number of colonies was in the range of 25 to 300 were taken into account. The number of colonies corresponds to the number of bacterial cells in the sample and is denoted as the number of the colony-forming units or CFUs. A total bacteria number, i.e., a total fungi number, is expressed as follows:

CFU per $g$ of a dried soil $=$

$=\frac{\text { number of colonies } x(100+\text { water content in a soil sample }(\%)) x \text { diluton factor }}{100}$

For the purpose of an agrochemical soil analysis, the soil samples were collected once per year (on 17 Jul. 2018 and on 3 Sept. 2019, respectively) at a depth of 0 to $30 \mathrm{~cm}$, in four repetitions, with a total of 24 soil samples collected. Concerning these samples, organic matter (\%) and $\mathrm{pH} \mathrm{KCl}$ were analyzed. The methodology used in these analyses corresponds to the ISO standards and methods published in the Republic of Croatia (ISO, 1994; ISO, 1998).

The meteorological stations have been set up in the field, recording the daily temperature (Vantage Pro2 DAV - 6152EU) (Table 1), whereas a soil temperature was measured in situ while sampling with a soil probe Aquaterr T-300 (Table 2).

Table 1. The average daily temperatures for the years 2018 and 2019

Tablica 1. Srednje dnevne temperature za 2018. i 2019. godinu

\begin{tabular}{|l|l|c|c|c|c|c|c|c|c|c|c|c|c|}
\hline \multicolumn{2}{|l|}{} & I & II & III & IV & V & VI & VII & VIII & IX & X & XI & XII \\
\hline 2018 & C, C+W & 4.6 & 0.5 & 4.7 & 17.0 & 20.6 & 21.5 & 22.7 & 24.3 & 18.1 & 14.2 & 7.1 & 1.7 \\
\hline \multirow{2}{*}{2019} & C & 0.3 & 4.4 & 9.6 & 11.9 & 15.9 & 22.6 & 22.3 & 23.1 & 17.5 & 14.5 & 7.1 & 3.7 \\
\cline { 2 - 35 } & C + W & 0.3 & 4.3 & 9.6 & 12.1 & 13.9 & 22.7 & 22.3 & 23.3 & 17.5 & 13.7 & 7.1 & 3.8 \\
\hline
\end{tabular}

$\mathrm{C}$ - agricultural crop, $\mathrm{C}+\mathrm{W}$ - agricultural crop + permanent walnut plantation

$C$ - poljoprivredna kultura, $C+W$ - poljoprivredna kultura + trajni nasad oraha

Table 2. Soil temperatures on the experimental surfaces at sampling times

Tablica 2. Temperature tla na eksperimentalnim površinama u vrijeme uzorkovanja

\begin{tabular}{|l|c|c|c|}
\hline Treatments / Tretmani & C & C + W & W \\
\hline 9 May 2018 / 9. 5. 2018. & 20.8 & 23.0 & 22.3 \\
\hline 20 Sept. 2018 / 20. 9. 2018. & 19.0 & 19.5 & 19.5 \\
\hline 3 Sept. 2019 / 3. 9. 2019. & 17.5 & 18.3 & 18.0 \\
\hline
\end{tabular}

$\mathrm{C}$ - agricultural crop, $\mathrm{C}+\mathrm{W}$ - agricultural crop + permanent walnut plantation, $\mathrm{W}$ - permanent walnut plantation

$C$ - poljoprivredna kultura, $C+W$ - poljoprivredna kultura + trajni nasad oraha, $W$ - trajni nasad oraha

The results obtained were statistically processed, and an analysis of variance (ANOVA) and Fisher's LSD test were calculated and administered using the SAS 9.1 software. A linear correlation between a total number of bacteria and fungi, organic matter (\%), and soil $\mathrm{pH}$ with the measured nematode parameters was obtained in Excel 2016.

\section{RESULTS AND DISCUSSION}

In this study, the impact of an agroforestry system on the nematode communities, bacteria and fungi abundance (biological soil properties), organic matter and $\mathrm{pH} \mathrm{KCl}$ were examined during the two years of the experimental period. Each treatment followed the organic farming principles to reduce a pesticide application impact on the nematode, bacteria, and fungi communities.
It can be seen in Tables 3, 4, and 5 that a $\mathrm{C}+$ W treatment had the statistically significant highest fungi abundance in all three sampling periods and the statistically significant highest bacteria abundance in the first and in the second sampling period when compared with the $\mathrm{C}$ and $\mathrm{W}$ treatments. According to Beule et al. (2020), a greater number of total soil bacteria and fungi was detected in a tree row than in the middle of a crop row $(24 \mathrm{~m}$ from the tree row) in agroforestry and in a monoculture cropland. However, the total soil bacteria and fungi from the crop row within a 1-meter and 7-meter distance were not significantly different from their abundance in the tree row. Our samples were taken approximately $4 \mathrm{~m}$ from the tree row, where a tree litter input and the abundant tree roots could contribute to the stimulation of soil microflora. 
Ekschmit et al. (2001) claim that the diversity of the nematode genera reflects both the abiotic conditions and a biotic activity of soils. It can be seen in the first and in the second sampling period (Tables 3 and 4) that the highest nematode abundance and generic diversity was in the $\mathrm{C}+\mathrm{W}$ treatment. Ekschmit et al. (2001) concluded that a high nematode richness, in terms of a number of genera, manifest consistent correlations with a nematofauna and microflora activity and mass in mineral grassland soils, being an optimal indicator of the organic matter decomposition rate. In the third sampling period, the highest nematode abundance was in the $\mathrm{C}$ treatment. A high percentage of bacterivorous nematodes in this treatment and sampling period (Table 5) and a high percentage of the CP-1 nematode amounting to $46.95 \%$ (unpublished data) could reflect some recent disturbance in that treatment.

Statistically, the C treatment had the highest percentage share of bacterivorous nematodes in each sampling period, indicating the organic matter decomposition through the bacterial pathways. A high percentage of fungivorous nematodes was recorded in the $\mathrm{W}$ treatment, indicating the organic matter decomposition through the fungal pathways, which takes place in a natural succession (Diemnot and Martin, 2005). On the other hand, a high abundance of bacteria, fungi, and nematodes, with a high percentage share of bacterivorous and fungivorous nematodes, was detected in the $C$ $+\mathrm{W}$ treatment. This indicates an equilibrium between the decomposers (Tables 3, 4, and 5) participating in the organic matter decomposition in the soil. A high bacterial and fungal activity, with the nematodes as secondary decomposers, results in the statistically significant highest organic matter content in the $\mathrm{C}+\mathrm{W}$ treatment in all sampling periods (Tables 3, 4, and 5). Agroforestry systems increase or maintain the organic matter in the soil (Young, 1985) and translocate the nutrients from the soil layers below the root levels of annual crops or grasses (Kellman, 1979). In addition, when shifting from the treeless systems to agroforestry, a storage of the organic carbon in the soil increases (De Stefano and Jacobson, 2018), which is a critical indicator of the soil health and assists in the mitigation of a climatic ecosystem change.

The highest percentage share of phytoparasitic nematodes in the $\mathrm{W}$ treatment in the first sampling (Table 3) can be compared with the results of Parmelee and Alston (1986), where they detected the highest number of phytoparasitic nematodes in the treatments with no-till farming, compared with the treatments applying conventional tillage. In the second sampling period (Table 4), the highest percentage share of phytoparasitic nematodes was in the $\mathrm{C}+\mathrm{W}$ treatment, which was under rapeseed as a green manure. Yeates (1979) claims that the abundance of phytoparasitic nematodes is closely related to the amount of root mass in the soil.

The highest percentage share of omnivores in our treatments was in the least disturbed W treatment, in the third sampling (Table 5), and a high percentage share of omnivorous nematodes is linked to the ecosystem stability and low disturbance. Predaceous nematodes (Tables 3 and 4) are linked to the fungivorous ones (Gomes et al., 2003), but in the third sampling period the predaceous nematodes were low in number or were not detected in the collected samples (Table 5).

Table 3. The number of bacteria, fungi, and nematodes, percentage share of the nematode trophic groups, soil pH and organic matter, 9 May 2018

Tablica 3. Broj bakterija, gljiva i nematoda, postotni udio trofičkih grupa nematoda, pH tla i sadržaj humusa, 9. 5. 2018.

\begin{tabular}{|l|c|c|c|}
\hline Treatments / Tretmani & C & C + W & W \\
\hline Number of bacteria / Broj bakterija & $810000^{\mathrm{C}}$ & $2156667^{\mathrm{A}}$ & $900000^{\mathrm{B}}$ \\
\hline Number of fungi / Broj gljiva & $7067^{\mathrm{B}}$ & $52667^{\mathrm{A}}$ & $4367^{\mathrm{C}}$ \\
\hline Number of nematodes / Broj nematoda & 145.50 & 238.75 & 106.50 \\
\hline Number of nematode genera / Broj rodova nematoda & 16.25 & 19.00 & 17.75 \\
\hline \% of bacterivores / \% bakterivora & $45.50^{\mathrm{A}}$ & $47.40^{\mathrm{A}}$ & $24.28^{\mathrm{B}}$ \\
\hline \% of fungivores / \% fungivora & 37.70 & 34.20 & 38.03 \\
\hline$\%$ of phytoparasites / \% biljnih parazita & $6.13^{\mathrm{B}}$ & $9.85^{\mathrm{B}}$ & $18.78^{\mathrm{A}}$ \\
\hline \% of omnivores / \% omnivora & 7.98 & 7.28 & 14.48 \\
\hline$\%$ of predators / \% predatora & 2.63 & 1.28 & 4.48 \\
\hline pH KCl & $4.18^{\mathrm{B}}$ & $5.48^{\mathrm{A}}$ & $5.77^{\mathrm{A}}$ \\
\hline Organic matter / Humus & $1.77^{\mathrm{B}}$ & $2.33^{\mathrm{A}}$ & $1.83^{\mathrm{B}}$ \\
\hline
\end{tabular}

$\mathrm{C}$ - agricultural crop, $\mathrm{C}+\mathrm{W}$ - agricultural crop + permanent walnut plantation, $\mathrm{W}$ - permanent walnut plantation

$C$ - poljoprivredna kultura, $C+W$ - poljoprivredna kultura + trajni nasad oraha $W$ - trajni nasad oraha

$A, B$ - different letters indicate significant differences among the treatments based on Fisher's $L S D$ test at $p \leq 0.05$

$A, B$ - različita slova označuju značajne razlike među tretmanima prema Fisherovu $L S D$ testu za $p \leq 0,05$ 
Table 4. The number of bacteria, fungi, and nematodes, percentage share of the nematode trophic groups, soil pH and organic matter, 20 Sept. 2018

Tablica 4. Broj bakterija, gljiva i nematoda, postotni udio trofičkih grupa nematoda, pH tla i sadržaj humusa, 20. 9. 2018.

\begin{tabular}{|c|c|c|c|}
\hline Treatments / Tretmani & C & $C+W$ & W \\
\hline Number of bacteria / Broj bakterija & $726667^{\mathrm{C}}$ & $1916667^{\mathrm{A}}$ & $793333^{B}$ \\
\hline Number of fungi / Broj gljiva & $6267^{\mathrm{B}}$ & $63000^{A}$ & $6533^{B}$ \\
\hline Number of nematodes / Broj nematoda & 262.00 & 455.50 & 364.80 \\
\hline Number of nematode genera / Broj rodova nematoda & 16.25 & 17.75 & 15.25 \\
\hline$\%$ of bacterivores / $\%$ bakterivora & $64.33^{\mathrm{A}}$ & $36.60^{\mathrm{B}}$ & $37.30^{\mathrm{B}}$ \\
\hline$\%$ of fungivores / \% fungivora & 20.20 & 13.38 & 25.65 \\
\hline$\%$ of phytoparasites / \% biljnih parazita & $10.30^{\mathrm{B}}$ & $44.23^{\mathrm{A}}$ & $28.70^{\mathrm{AB}}$ \\
\hline$\%$ of omnivores / $\%$ omnivora & 3.28 & 4.60 & 3.65 \\
\hline$\%$ of predators / $\%$ predatora & 1.88 & 1.23 & 4.68 \\
\hline $\mathrm{pH} \mathrm{KCl}$ & $4.18^{\mathrm{B}}$ & $5.48^{\mathrm{A}}$ & $5.77^{\mathrm{A}}$ \\
\hline Organic matter / Humus & $1.77^{\mathrm{B}}$ & $2.33^{\mathrm{A}}$ & $1.83^{\mathrm{B}}$ \\
\hline
\end{tabular}

$\mathrm{C}$ - agricultural crop, $\mathrm{C}+\mathrm{W}$ - agricultural crop + permanent walnut plantation, $\mathrm{W}$ - permanent walnut plantation

$C$ - poljoprivredna kultura, $C+W$ - poljoprivredna kultura + trajni nasad oraha $W$-trajni nasad oraha

$A, B$ - different letters indicate significant differences among the treatments based on Fisher's LSD test at $p \leq 0.05$.

$A, B$ - različita slova označuju značajne razlike među tretmanima prema Fisherovu $L S D$ testu za $p \leq 0,05$

Table 5. Number of bacteria, fungi and nematodes, percentage share of the nematode trophic and CP groups, soil pH and organic matter, 3 Sept. 2019

Tablica 5. Broj bakterija, gljiva i nematoda, postotni udio trofičkih i CP grupa nematoda, pH tla i sadržaj humusa, 3. 9. 2019.

\begin{tabular}{|c|c|c|c|}
\hline Treatments / Tretmani & C & $C+W$ & W \\
\hline Number of bacteria / Broj bakterija & $460000^{B}$ & $67000^{C}$ & $526667^{\mathrm{A}}$ \\
\hline Number of fungi / Broj gljiva & $17833^{B}$ & $38667^{\mathrm{A}}$ & $22733^{B}$ \\
\hline Number of nematodes / Broj nematoda & 190.00 & 114.50 & 127.00 \\
\hline Number of nematode genera / Broj rodova nematoda & 13.25 & 14.25 & 15.25 \\
\hline$\%$ of bacterivores / $\%$ bakterivora & $76.20^{\mathrm{A}}$ & $62.40^{\mathrm{B}}$ & $45.40^{C}$ \\
\hline$\%$ of fungivores / \% fungivora & $10.15^{\mathrm{B}}$ & $23.10^{\mathrm{AB}}$ & $30.28^{A}$ \\
\hline$\%$ of phytoparasites / \% biljnih parazita & 10.90 & 13.08 & 15.98 \\
\hline$\%$ of omnivores / \% omnivora & $2.50^{\mathrm{AB}}$ & $1.48^{\mathrm{B}}$ & $8.38^{\mathrm{A}}$ \\
\hline$\%$ of predators / $\%$ predatora & 0.23 & 0.00 & 0.00 \\
\hline $\mathrm{pH} \mathrm{KCl}$ & $4.15^{B}$ & $4.61^{\mathrm{AB}}$ & $5.28^{\mathrm{A}}$ \\
\hline Organic matter / Humus & $1.75^{\mathrm{B}}$ & $2.20^{\mathrm{A}}$ & $2.40^{\mathrm{A}}$ \\
\hline
\end{tabular}

$\mathrm{C}$ - agricultural crop, $\mathrm{C}+\mathrm{W}$ - agricultural crop + permanent walnut plantation, $\mathrm{W}$ - permanent walnut plantation

$C$ - poljoprivredna kultura, $C+W$ - poljoprivredna kultura + trajni nasad oraha $W$ - trajni nasad oraha

$A, B$ - different letters indicate significant differences among the treatments based on Fisher's LSD test at $p \leq 0.05$.

$A, B$ - različita slova označuju značajne razlike među tretmanima prema Fisherovu LSD testu za $p \leq 0,05$

A linear correlation between the number of bacteria and fungi, organic matter, $\mathrm{pH}$ and nematode abundance and trophic groups in three different agroecosystems observed is calculated and figured in Table 6. A nematode abundance, featured as a nematode number per sample, had a positive correlation with a bacterial abundance in the $\mathrm{C}+\mathrm{W}$ treatment only. In C and W treatments, the correlation is not significant. The nematode abundance manifests a negative correlation with a fungal abundance in the $\mathrm{C}$ and $\mathrm{W}$ treatments, but a strong positive correlation in the $\mathrm{C}+\mathrm{W}$ treatment. The diversity of the nematode genera is positively correlated with a bacterial abundance in the samples regardless of the treatment, while the diversity of the nematode genera manifests a positive correlation with a fungal abundance in the $\mathrm{C}+\mathrm{W}$ treatment only. The bacterial abundance had a high positive correlation with the fungal abundance in the $\mathrm{C}+\mathrm{W}$ treatment, which indicates a balance of both fungal and bacterial pathways of organic matter decomposition and nitrogen mineralization (Diemnot and Martin, 2005). However, in the $C$ and 
W treatments, respectively, a correlation between a bacterial and fungal abundance was highly negative. The organic matter content in the soil manifested a weak positive correlation with both the bacterial and fungal abundance in the $\mathrm{C}+\mathrm{W}$ treatment, a strong positive correlation with the fungi in the $\mathrm{W}$ treatment, and a strong negative correlation with the bacteria in the latter treatment. There was no correlation detected in the $\mathrm{C}$ treatment between the organic matter and a bacterial and fungal abundance. The organic matter in the soil is a source of inorganic nutrients for the plants but also a substrate for microorganisms and a vital factor in the soil and water conservation (Sanchez, 1987). An increased decomposition through the fungal pathways enhances the organic matter retention because the fungi withhold a higher percentage of carbon (Adu and Oades, 1978) and produce more recalcitrant organic fractions than the bacteria do (Sanchez, 1987).

The $C+W$ treatment manifests the highest abundance of bacteria, fungi, and nematodes and a generic nematode diversity when compared with $\mathrm{C}$ and $\mathrm{W}$ treatment, for the first and the second sampling. Between mentioned parameters, a positive linear correlation was found. Wagg et al. (2013) show that ecosystem functions such as decomposition, nutrient retention, and nutrient cycling have a strong positive linear relationship with soil biodiversity. Therefore, a high biodiversity in the $\mathrm{C}+\mathrm{W}$ treatment indicates the most favorable ecosystem multifunctionality and sustainability when compared with the $\mathrm{C}$ and $\mathrm{W}$ treatments. Agroforestry has a great potential for the elevation of soil fertility through a more efficient nutrient cycling (Nair, 1984). Two decades of biodiversity research (Wagg et al., 2013) have demonstrated that a plant diversity above the ground is of an extreme importance in the functioning of every ecosystem and affects a below-ground biodiversity. Soil biodiversity supports the main ecosystem processes, suggesting that its protection is significant for all ecosystems' sustainability. Agroforestry, as multifunctional land-use management, should be in the spotlight of scientific research and agricultural practices for a better soil future and health. Also, a further research is essential for better understanding of the impact of different agroforestry ecosystems on soil functioning and its biodiversity.

Table 6. A correlation between the number of bacteria and fungi, organic matter (\%), soil pH and the measured nematode community parameters (all treatments and sampling times)

Tablica 6. Korelacija između broja bakterija i gljiva, humusa, pH tla i mjerenih parametara zajednice nematoda (svi tretmani i vremena uzorkovanjal

\begin{tabular}{|c|c|c|c|c|c|c|c|c|c|c|}
\hline & & $\begin{array}{l}\mathrm{N} \text { of bacteria } \\
N \text { bakterija }\end{array}$ & $\begin{array}{l}\mathrm{N} \text { of fungi } \\
N \text { gljiva }\end{array}$ & $\begin{array}{c}\mathrm{N} \text { of } \\
\text { nematodes } \\
N \text { nematoda }\end{array}$ & $\begin{array}{c}\mathrm{N} \text { of nematode } \\
\text { genera } \\
N \text { rodova nematoda }\end{array}$ & $\begin{array}{l}\mathrm{Ba} \\
\%\end{array}$ & $\begin{array}{r}\mathrm{Fu} \\
\%\end{array}$ & $\begin{array}{l}\mathrm{Pp} \\
\%\end{array}$ & $\begin{array}{l}0 \mathrm{~m} \\
\%\end{array}$ & $\begin{array}{l}\operatorname{Pr} \\
\%\end{array}$ \\
\hline & $\begin{array}{l}\mathrm{N} \text { of bacteria } \\
N \text { bakterija }\end{array}$ & - & -0.85 & -0.06 & 0.47 & -0.71 & 0.77 & -0.25 & 0.48 & 0.66 \\
\hline \multirow[t]{3}{*}{ C } & $\begin{array}{l}\mathrm{N} \text { of fungi } \\
N \text { gljiva }\end{array}$ & - & - & -0.21 & -0.49 & 0.46 & -0.56 & 0.34 & -0.33 & -0.60 \\
\hline & $\begin{array}{l}\text { Organic matter } \\
\text { Humus }\end{array}$ & 0.10 & 0.05 & 0.04 & -0.39 & -0.03 & 0.09 & -0.11 & 0.01 & -0.08 \\
\hline & $\mathrm{pH} \mathrm{KCl}$ & -0.03 & -0.04 & 0.34 & 0.25 & 0.13 & -0.29 & 0.31 & -0.06 & 0.11 \\
\hline \multirow{4}{*}{$\begin{array}{l}\mathrm{C} \\
+ \\
W\end{array}$} & $\begin{array}{l}\mathrm{N} \text { of bacteria } \\
N \text { bakterija }\end{array}$ & - & 0.75 & 0.47 & 0.64 & -0.74 & 0.09 & 0.31 & 0.78 & 0.47 \\
\hline & \begin{tabular}{|l}
$\mathrm{N}$ of fungi \\
$N$ gljiva \\
\end{tabular} & - & - & 0.45 & 0.33 & -0.78 & -0.29 & 0.68 & 0.39 & 0.40 \\
\hline & $\begin{array}{l}\text { Organic matter } \\
\text { Humus }\end{array}$ & 0.25 & 0.31 & -0.09 & 0.05 & -0.01 & -0.28 & 0.17 & 0.28 & -0.15 \\
\hline & $\mathrm{pH} \mathrm{KCl}$ & 0.59 & 0.45 & 0.05 & 0.18 & -0.25 & -0.09 & 0.14 & 0.57 & 0.03 \\
\hline \multirow{4}{*}{ W } & $\begin{array}{l}\mathrm{N} \text { of bacteria } \\
N \text { bakterija }\end{array}$ & - & -0.95 & 0.07 & 0.29 & -0.73 & 0.18 & 0.20 & 0.20 & 0.51 \\
\hline & $\begin{array}{l}N \text { of fungi } \\
N \text { gljiva }\end{array}$ & - & - & -0.28 & -0.26 & 0.71 & -0.13 & -0.25 & -0.14 & -0.51 \\
\hline & $\begin{array}{l}\text { Organic matter } \\
\text { Humus }\end{array}$ & -0.92 & 0.97 & -0.41 & -0.27 & 0.61 & -0.13 & -0.19 & -0.12 & -0.45 \\
\hline & $\mathrm{pH} \mathrm{KCl}$ & 0.16 & -0.21 & 0.11 & 0.15 & 0.01 & 0.17 & -0.02 & -0.13 & -0.17 \\
\hline
\end{tabular}

$\mathrm{C}$ - agricultural crop, $\mathrm{C}+\mathrm{W}$ - agricultural crop + permanent walnut plantation, $\mathrm{W}$ - permanent walnut plantation

$C$ - poljoprivredna kultura, $C+W$ - poljoprivredna kultura + trajni nasad oraha, W- trajni nasad oraha

Nematode trophic groups: $\mathrm{Ba}$ - bacterivores, $\mathrm{Fu}$ - fungivores, $\mathrm{Pp}$ - phytoparasites, $\mathrm{Om}$ - omnivores, $\mathrm{Pr}$ - predators

Trofičke grupe nematoda: $\mathrm{Ba}$ - bakterivore, $\mathrm{Fu}$ - fungivore, $\mathrm{Pp}$ - biljni paraziti, $\mathrm{Om}$ - omnivore, $\mathrm{Pr}$ - predatori

Bold coefficient of correlation is associated with high positive or negative correlation $\left.{ }^{* *}\right)$

Podebljani koeficijent korelacije označuje visoku pozitivnu ili negativnu korelaciju (**) 


\section{CONCLUSION}

In this field experiment, we have studied the nematodes, bacteria, and fungi in an agroforestry ecosystem (treatment $\mathrm{C}+\mathrm{W}$ ) in comparison with an agricultural crop (treatment $\mathrm{C}$ ) and a permanent walnut plantation (W). Our findings suggest that the studied agroforestry ecosystem $(C+W)$ exerted a positive effect on the soil nematodes and microorganisms, manifested as the statistically highest abundance of bacteria and fungi, but also the highest abundance of nematodes and nematode diversity. A high abundance of bacteria and fungi and a high percentage share of bacterivores and fungivores in the $\mathrm{C}+\mathrm{W}$ treatment indicated an equilibrium between the decomposers participating in the organic matter decomposition, which resulted in the statistically significant highest organic matter content in the $C+W$ treatment in the first sampling period. In the last sampling period, the highest organic matter content was detected in the $C+W$ treatments and the $W$ treatment. The $\mathrm{C}+\mathrm{W}$ treatment manifested a high positive correlation between a bacteria and fungi abundance and between a bacteria and fungi abundance and nematode diversity. We have concluded that the combination of an agricultural crop and a permanent plantation has a great potential concerning a better ecosystem stability and sustainability. Given that the agroforestry systems are diverse, we encourage the more comprehensive studies to examine an effect of different agroforestry ecosystems on the soil fauna.

\section{ACKNOWLEDGEMENTS}

We hereby express our gratitude to the Croatian Science Foundation for its support and financing of our project entitled UIP-2017-05, 7103, AGROINOVA Intercropping of Wood Species and Agricultural Crops as an Innovative Approach in Agroecosystems and to the Jela Paponja Family Farm for a substantial assistance in the field experiment.

\section{REFERENCES}

1. Adu, J. K., \& Oades, J. M. (1978). Utilization of organic materials in soil aggregates by bacteria and fungi. Soil Biology and Biochemistry, 10(2), 117-122.

2. Andrassy, I. (2005). Pedozoologica Hungarica No. 3.: Free-living nematodes of Hungary (Nematoda errantia) Volume I, Hungarian National History Museum, Budapest, Hungary

3. Andrassy, I. (2007). Pedozoologica Hungarica No. 4.: Free-living nematodes of Hungary (Nematoda errantia) Volume II, Hungarian National History Museum, Budapest, Hungary

4. Andrassy, I. (2009). Pedozoologica Hungarica No. 5.: Free-living nematodes of Hungary (Nematoda errantia) Volume III, Hungarian National History Museum, Budapest, Hungary

5. Bardgett, R. D., \& Chan, K. F. (1999). Experimental evidence that soil fauna enhance nutrient mineralization and plant nutrient uptake in montane grassland ecosystems. Soil Biology and Biochemistry, 31(7), 1007-1014.

6. Bardgett, R. D., \& Van Der Putten, W. H. (2014). Belowground biodiversity and ecosystem functioning. Nature, 515(7528), 505-511.

https://doi.org/10.1038/nature13855

7. Beule, L., Lehtsaar, E., Corre, M. D., Schmidt, M., Veldkamp, E., \& Karlovsky, P. (2020). Poplar rows in temperate agroforestry croplands promote bacteria, fungi, and denitrification genes in soils. Frontiers in Microbiology, 10, 3108.

https://doi.org/10.3389/fmicb.2019.03108

8. Bongers, T. (1990). The maturity index: an ecological measure of environmental disturbance based on nematode species composition. Oecologia, 83(1), 14-19.

9. Bongers, T. (1994). De Nematoden van Nederland. KNNV-bibliotheekuitgave 46. 408. Pirola, Schoorl.

10. Bongers, T., \& Bongers, M. (1998). Functional diversity of nematodes. Applied Soil Ecology, 10(3), 239-251. https://doi.org/10.1016/S0929-1393(98)00123-1

11. Brmež, M., Puškarić, J., Siber, T., Raspudić, E., Grubišić, D., \& Popović, B. (2018). Influence of liquid chicken manure preparation on soil health and agrochemical soil properties. Poljoprivreda, 24(1), 3-9.

12. De Goede, R. G. M. (1993). Terrestrial nematodes in a changing environment.

13. De Stefano, A., \& Jacobson, M. G. (2018). Soil carbon sequestration in agroforestry systems: a meta-analysis. Agroforestry Systems, 92(2), 285-299. https://doi.org/10.1007/s10457-017-0147-9

14. Diemont, S. A., \& Martin, J. F. (2005). Management impacts on the trophic diversity of nematode communities in an indigenous agroforestry system of Chiapas, Mexico. Pedobiologia, 49(4), 325-334.

15. Dupraz, C., Burgess, P., Gavaland, A., Graves, A., Herzog, F., Incoll, L., ... \& Liagre, F. (2005). Synthesis of the silvoarable agroforestry for Europe project. INRA-UMR System Editions, Montpellier, 254.

16. Ekschmitt, K., Bakonyi, G., Bongers, M., Bongers, T., Boström, S., Dogan, H., ... \& Sohlenius, B. (1999). Effects of the nematofauna on microbial energy and matter transformation rates in European grassland soils. Plant and Soil, 212(1), 45-61.

17. Ekschmitt, K., Bakonyi, G., Bongers, M., Bongers, T., Boström, S., Dogan, H., ... \& Sohlenius, B. (2001). Nematode community structure as indicator of soil functioning in European grassland soils. European Journal of Soil Biology, 37(4), 263-268.

18. Ferris, H., \& Tuomisto, H. (2015). Unearthing the role of biological diversity in soil health. Soil Biology and Biochemistry, 85, 101-109.

https://doi.org/10.1016/j.soilbio.2015.02.037

19. Ferris, H., Venette, R. C., Van Der Meulen, H. R., \& Lau, S. S. (1998). Nitrogen mineralization by bacterial-feeding nematodes: verification and measurement. Plant and Soil, 203(2), 159-171

20. Gomes, G. S., Huang, S. P., \& Cares, J. E. (2003). Nematode community, trophic structure and population fluctuation in soybean fields. Fitopatologia brasileira, 28(3), 258-266. 
21. Ingham, R. E., Trofymow, J. A., Ingham, E. R., \& Coleman, D. C. (1985). Interactions of bacteria, fungi, and their nematode grazers: effects on nutrient cycling and plant growth. Ecological Monographs, 55(1), 119-140.

22. International Standard Organisation [ISO 10390: 1994] (1994) Soil quality - Determination of $\mathrm{pH}$.

23. International Standard Organisation, [ISO 151412:1998] (1998) Foodstuffs - Determination of ochratoxin $A$ in cereals and cereal products -- Part 2: High performance liquid chromatographic method with bicarbonate clean up.

24. Kandji, S. T., Ogol, C. K., \& Albrecht, A. (2003). Crop damage by nematodes in improved-fallow fields in western Kenya. Agroforestry Systems, 57(1), 51-57.

25. Kellman, M. (1979). Soil enrichment by neotropical savanna trees. The Journal of Ecology, 67(2), 565-577. https://doi.org/10.2307/2259112

26. Kibblewhite, M. G., Ritz, K., \& Swift, M. J. (2008). Soil health in agricultural systems. Philosophical Transactions of the Royal Society B: Biological Sciences, 363(1492), 685-701. https://doi.org/10.1098/rstb.2007.2178

27. Mai, W. F., \& Lyon, H. H. (1975). Pictorial key to genera of plant-parasitic nematodes. 219. London. Cornell University Press.

28. Nair, P. K. R., \& Nair, P. R. (1984). Soil productivity aspects of agroforestry (Vol. 1). Nairobi, Kenya: International Council for Research in Agroforestry.

29. Neher, D. A., Easterling, K. N., Fiscus, D., \& Campbell, C. L. (1998). Comparison of nematode communities in agricultural soils of North Carolina and Nebraska. Ecological Applications, 8(1), 213-223. https://doi.org/10.2307/2641323

30. Neher, D. A., Wu, J., Barbercheck, M. E., \& Anas, 0. (2005). Ecosystem type affects interpretation of soil nematode community measures. Applied Soil Ecology, 30(1), 47-64. https://doi.org/10.1016/j.apsoil.2005.01.002

31. Parmelee, R. W., \& Alston, D. G. (1986). Nematode trophic structure in conventional and no-tillage agroecosystems. Journal of Nematology, 18(3), 403-407.

32. Ritz, K., \& Trudgill, D. L. (1999). Utility of nematode community analysis as an integrated measure of the functional state of soils: perspectives and challenges. Plant Soil, 212(1), 1-11.

https://www.jstor.org/stable/42949670

33. Sanchez, P. A. (1987). Soil productivity and sustainability in agroforestry systems. Agroforestry: A decade of development, 205-223.

34. Urzelai, A., Hernández, A. J., \& Pastor, J. (2000). Biotic indices based on soil nematode communities for assessing soil quality in terrestrial ecosystems. Science of the Total Environment, 247(2-3), 253-261.

35. Van Bezooijen, J. (2006). Methods and techniques for nematology (p. 20). Wageningen, The Netherlands: Wageningen University.

36. Venette, R. C., \& Ferris, H. (1998). Influence of bacterial type and density on population growth of bacterial-feeding nematodes. Soil Biology and Biochemistry, 30(7), 949-960.

37. Verchot, L. V., Van Noordwijk, M., Kandji, S., Tomich, T., Ong, C., Albrecht, A., ... \& Palm, C. (2007). Climate change: linking adaptation and mitigation through agroforestry. Mitigation and Adaptation Strategies for Global Change, 12(5), 901-918.

38. Wagg, C., Bender, S. F., Widmer, F., \& van der Heijden, M. G. (2014). Soil biodiversity and soil community composition determine ecosystem multifunctionality. Proceedings of the National Academy of Sciences, 111(14), 5266-5270. https://doi.org/10.1073/pnas.1320054111

39. Wasilewska, L. (1997). Soil invertebrates as bioindicators, with special reference to soil-inhabiting nematodes. Russian Journal of Nematology, 5(2), 113-126.

40. Yeates, G. W. (1979). Soil nematodes in terrestrial ecosystems. Journal of Nematology, 11(3), 213-229.

41. Yeats, G. W., Bongers, T., De Goede, R. G. M., Freckman, D. W., \& Georgieva, S. S. (1993). Feeding Habits in Soil Nematode Families and Genera - An Outline for Soil Ecologists. Journal of Nematology, 25(3), 315-331.

42. Young, A. (1985). The potential of agroforestry as a practical means of sustaining soil fertility. ICRAF Working Papers, 1-28. https://pdf.usaid.gov/pdf_docs/PNABE218.pdf 


\section{ZAJEDNICE NEMATODA, BAKTERIJA I GLJIVA I SADRŽAJ HUMUSA U AGROŠUMARSKOME EKOSUSTAVU U HRVATSKOJ}

\section{SAŽETAK}

Biljna raznolikost iznad tla utječe na biološku raznolikost u tlu. Raznolikost faune tla važna je za održivost ekosustava, a odražava i abiotske uvjete i biotičku aktivnost tla. Cilj ovoga istraživanja bio je utvrditi utjecaj agrošumarskih sustava na faunu nematoda u tlu, brojnost nematoda, distribuciju trofičkih grupa nematoda $i$ brojnost bakterija $i$ gljiva u tlu te analizirati povezanost između hranidbenih grupa nematoda, mikrobiološkoga statusa tla $i$ humusa. Poljski pokus proveden je tijekom dviju godina u trima tretmanima i tijekom triju vremena uzorkovanja. Tretmani su bili sljedeći: poljoprivredna kultura (C), trajni nasad oraha (W) i trajni nasad oraha s poljoprivrednom kulturom (C $+W$. Nematode su izdvojene, prebrojene, pripremljene u preparate, determinirane te podijeljene u trofičke grupe. Bakterije i gljive su izdvojene iz tla, uzgajane na podlogama i prebrojene. Naši rezultati sugeriraju da je proučeni agrošumarski sustav $(C+W)$ imao pozitivan utjecaj na nematode, bakterije i gljive u tlu, što je prikazano kao statistički najveća brojnost bakterija i gljiva, ali $i$ kao najveća brojnost nematoda i bioraznolikost rodova nematoda. Najveći sadržaj humusa pronađen u prvome uzorkovanju jest onaj u tretmanu $C+W$, a u drugome uzorkovanju u tretmanima $C+W$ i W. Zaključili smo da kombinacija poljoprivredne kulture i trajnih nasada ima velik potencijal za bolju stabilnost $i$ održivost ekosustava, bez obzira na neka odstupanja u našim rezultatima. Smatramo da su potrebna daljnja istraživanja, jer različiti agrošumarski ekosustavi mogu imati različit utjecaj na faunu tla.

Ključne riječi: trofičke grupe nematode, fauna tla, mikroorganizmi, nasad oraha, poljoprivredna kultura

(Received on November 24, 2020; accepted on April 27, 2021 - Primljeno 24. studenoga 2020.; prihvaćeno 27. travnja 2021.) 